\title{
Utjecaj ultrazvuka i visokog hidrostatskog tlaka na fizikalna svojstva sojinog mlijeka kao baze za pripravu napitaka
}

\section{Influence of ultrasound and high hydrostatic pressure on the physical properties of soymilk as a base for the production of beverages}

\author{
Tomislav Bosiljkov*, Domagoj Kurtoić, Sven Karlović, Mladen Brnčić, Filip Dujmić, Marko Marelja, \\ Marko Škegro, Damir Ježek
}

Prehrambeno-biotehnološki fakultet Sveučilišta u Zagrebu, Pierottijeva 6, 10000 Zagreb, Hrvatska

* Corresponding author: tbosilj@pbf.hr

Sažetak

Netoplinske tehnologije, danas sve zastupljenije u modernoj prehrambenoj industriji zasnivaju se na brzoj i učinkovitoj obradi kojom u potpunosti kontroliramo promjenu temperaturnog gradijenta. Sojino mlijeko kao vodeni ekstrakt sojina zrna prihvatljiva je baza za proizvodnju napitaka na bazi voća i povrća kao i pripravu sve popularnijih smoothija. Cilj ovog rada bio je istražiti utjecaj ultrazvuka visokog intenziteta $i$ visokog hidrostatskog tlaka na promjenu fizikalnih svojstava (temperatura, apsorbancija, gustoća i raspodjela veličine masnih globula) sojinog mlijeka sa različitim udjelom suhe tvari sa ciljem bolje stabilnosti i održanja disperznog sustava. Udio suhe tvari reflektira se na stabilnost disperzne faze unutar disperznog sredstva. Ultrazvučna obrada provedena je pri amplitudama 20, 60 i $100 \%$, vremenu obrade $6 i 10$ minuta, te sondama promjera 7 i $10 \mathrm{~mm}$. Obrada visokim hidrostatskim tlakom provedena je pri tlakovima od 100, 200 i 300 Mpa $i$ vremenu zadržavanja od 9 i 15 min. Obje netoplinske tehnologije pokazuju pozitivan trend utjecaja na statistički značajnu promjenu promatranih fizikalnih svojstava kao i povećanje stabilnost obrađenog sojinog mlijeka izraženog preko odnosa relativne učestalosti globula određenih dimenzija.

Ključne riječi: sojino mlijeko, visoki hidrostatski tlak, ultrazvuk, raspodjela veličine masnih globula

Abstract

The novel, nonthermal technologies are represented in the modern food industry, as a fast and efficient processes which are based on total control of the temperature gradient. Soy milk as a water extract of soybean is an acceptable base for manufacturing of beverages based on fruit, vegetables and all kind of smoothies. The main goal of this manuscript is an exploration of the influence of high-intensity ultrasound and high hydrostatic pressure on changes of physical properties such as temperature, absorbance, density and fat globule distribution of soymilk with different ratio of dry matter content. Dry matter content is reflected on the stability of dispersed phase against the dispersed agent. Ultrasonic treatment was performed at amplitude of 20,60 and $100 \%$, time of 6 and 10 minutes using 7 and 10 mm probes. High hydrostatic pressure treatment was performed at 100, 200 and $300 \mathrm{MPa}$ and time of treatment 9 and 15 minutes. Both, nonthermal technologies have a statistically significant influence on observed physical properties as well as increasing of stability treated soymilk expressed over frequency curve against the diameter of fat globules.

Keywords: soymilk, high hydrostatic pressure, ultrasound, fat globule distribution

Uvod

Proizvodnja i potrošnja voćnih, povrtnih sokova i smoothija u stalnom je porastu na globalnoj razini. Primjena netoplinskih tehnologija u prehrambenoj tehnologiji i biotehnologiji sve je intenzivnija, posebno primjena visokog hidrostatskog tlaka i ultrazvuka visokog intenziteta. (Picouet i sur., 2016). Utjecaj netoplinskih tehnologija najčešće se manifestira kao vrlo učinkovita metoda obrade svježih namirnica sa ciljem potpunog očuvanja izvornosti tako obrađenih uzoraka (Indrawati i sur., 2002; Martínez - Monteagudo i Balasubramaniam, 2015). Od izuzetne važnosti je kontrola temperature procesa obrade koja najčešće ne prelazi vrijednosti koje bi bitno utjecale na fizikalno - kemijske komponente svježe obrađenih namirnica. Svakodnevna konzumacija svježe obrađenog voća i povrća u količini od $400 \mathrm{~g}$ po preporuci „Svjetske zdravstvene organizacije“ najučinkovitiji je put prema prevenciji većine bolesti modernog društva. Osim voćnih i povrtnih sokova na tržištu su sve prisutniji i smoothiji, sokovi dobiveni iz više različitih komponenata odabranog svježeg voća i povrća. Kao baza, najčešće se koristi kravlje i sojino mlijeko zbog svojih izrazito dobrih prirodno emulgirajućih svojstava koja pružaju dodatnu stabilnost višekomponentnim sustavima (Bosiljkov, 
2011; Picouet i sur., 2016). Sojino mlijeko kao prirodni ekstrakt sojinog zrna svojim kemijskim sastavom pokazao se kao izvrstan odabir za široku populaciju koja ima intoleranciju na laktozu, kao zdravi obrok sa visokim udjelom proteina (Toro - Funes i sur., 2014). Komercijalno iskorištenje visokog hidrostatskog tlaka promatrajući kroz prizmu materijalne i energetske bilance dobivanja voćnih, povrtnih sokova i smoothija, događa se pri tlakovima od 300 - $600 \mathrm{MPa}$ i vremenu zadržavanja do 10 minuta. Za svako povećanje tlaka od $100 \mathrm{MPa}$ u sustavu dolazi do povećanja temperature od $3-6{ }^{\circ} \mathrm{C}$ ovisno o promatranoj komponenti (voda, proteini, masti) (Tewari, 2007; Bosiljkov i sur., 2010; Fernandez i sur., 2018). Djelovanje ultrazvuka visokog intenziteta zasniva se na rasprostiranju ultrazvučnog vala u tekućem mediju i posljedično o imploziji kavitacijskog mjehurića tijekom prijelazne kavitacije koja najčešće ovisi o frekvencijskom području odabranog ultrazvučnog procesora (Bosiljkov i sur., 2017; Komes i sur., 2017). Primjena netoplinskih tehnologija najčešće je sa ciljem mikrobiološke obrade, tj. inaktivacije mikroorganizama i enzima sa ciljem produljenja trajnosti i svježine. Homogenizacija visokim tlakom i ultrazvukom ima za posljedicu povećanje stabilnosti grubo disperznih sustava. Termin homogenizacija koristi se za procese $u$ kojima dolazi do redukcije veličine neravnomjerno disperznog sustava i postizanja veće disperznosti u sustavu frekvencije raspodjele veličine masnih globula (Karlović i sur., 2014; Poliseli Scopel i sur., 2012). Cilj ovog rada bio je istražiti utjecaj ultrazvuka visokog intenziteta i visokog hidrostatskog tlaka na promjenu fizikalnih svojstava sojinog mlijeka sa različitim udjelom suhe tvari sa ciljem postizanja bolje stabilnosti i održivosti disperznog sustava kao baze za proizvodnju napitaka.

\section{Materijali i metode}

Mjerenja su provedena na sojinom mlijeku, pripremljenom iz tri različite mase zrna: $50 \mathrm{~g}$ (99\% vode; $1 \%$ suhe tvari), 90 g (98 \% vode; $2 \%$ suhe tvari) i 130 g (97\% vode; $3 \%$ suhe tvari). Sirovo sojino zrno postavlja se u mrežicu ekstraktora (uređaj „Soylove“, Južna Koreja) koja je uronjena u $1800 \mathrm{~mL}$ vode i zagrijana na $80^{\circ} \mathrm{C}$. Nakon mljevenja, ekstrakcije i hlađenja mlijeko se filtrira i pohranjuje u hladnjak na $4{ }^{\circ} \mathrm{C}$. Prije same obrade mlijeko se temperira na $20^{\circ} \mathrm{C}$.

\section{Obrada visokim hidrostatskim tlakom i ultrazvukom}

Za obradu visokim hidrostatskim tlakom korišten je uređaj „Stansted Fluid Power“, Velika Britanija. Uzorci su obrađeni u plastičnim bocama od $100 \mathrm{~mL}$. Početna temperatura uzorka iznosila je $20{ }^{\circ} \mathrm{C}$. Primijenjeni su tlakovi od 100, $200 \mathrm{i}$ $300 \mathrm{MPa} u$ vremenu od 9 i 15 minuta. Za obradu ultrazvukom korišten je ultrazvučni procesor marke „Hielscher", Njemačka, oznake UP $100 \mathrm{H}$ maksimalne snage od $100 \mathrm{~W}$ pri konstantnoj frekvenciji od $30 \mathrm{kHz}$. Volumen uzorka iznosio je $150 \mathrm{~mL}$ i obrađen je u laboratorijskim čašama od $400 \mathrm{~mL}$. Početna temperatura uzorka iznosila je $20{ }^{\circ} \mathrm{C}$. Mjerenja su provedena pri vrijednostima amplitude od 20, 60 i $100 \%$ u vremenu od 6 i 10 minuta pri punom ciklusu. Korištene su sonde promjera 7 i 10 mm uronjene $2 \mathrm{~cm} \mathrm{u}$ uzorak.

\section{Mjerenje temperature, gustoće i apsorbancije}

Tijekom ultrazvučne obrade uzorcima je mjerena temperatura (,Raytek“, Velika Britanija) svakih 30 sekundi s udaljenosti od $15 \mathrm{~cm}$, usmjeravanjem pomoćne laserske zrake na sredinu promatranog uzorka, te očitavanjem temperature korištenjem pasivnog infracrvenog detektora. Emisivnost je bila podešena na 0,92 . Za mjerenje gustoće korišten je uređaj „Mettler Toledo Density Meter DE 40“, Švicarska. Uzorak se ubrizgava u ispranu U - cijev, a vrijednost gustoće dobije se direktnim očitanjem nakon automatske korekcije temperature na $20{ }^{\circ} \mathrm{C}$. Mjerenje apsorbancije provedeno je pri $500 \mathrm{~nm}$ u kiveti promjera $1 \mathrm{~cm}$. Za mjerenje je korišten kolorimetar „KONICA - MINOLTA CM - 3500 - d“", Japan. Vrijednosti apsorbancija očitane su pomoću računalnog programa „Spectra MagixTM NX Ver. 1.7.“, „Color Data Software CM - S 100W“. Mjerenje je ponovljeno u istim uvjetima nakon 24 sata.

\section{Određivanje raspodjele veličine čestica (masnih globula)}

Raspodjela veličine čestica određivana je prije i nakon obrade uzorka ultrazvukom i visokim hidrostatskim tlakom. Za određivanje raspodjele veličine čestica korišten je laserski analizator za raspodjelu veličine čestica mjernog raspona od 0,02 do $2000 \mu \mathrm{m}$ (,Mastersizer 2000“, Velika Britanija).

\section{Statistička analiza}

Rezultati su obrađeni pomoću programa „Statistica 12“. Statistička značajnost utjecaja procesnih parametara određena je analizom varijance (ANOVA) i izražena preko $p$-vrijednosti. Svi parametri koji su imali vrijednost $p<0,05$ ( $95 \%$ - tna razina značajnosti) uzeti su u obzir. Utjecaj procesnih parametara izražen je brojčanom vrijednosti $\beta$-standardiziranog koeficijenta utjecaja očitanih iz Pareto dijagrama. Izmjerene su tri paralele svakog uzorka.

\section{Rezultati i rasprava}

Utjecaj procesnih parametara ultrazvuka i visokog hidrostatskog tlaka na promatrana fizikalna svojstva prikazan je u Tablici 1 prema odgovarajućim $\beta$ - koeficijentima temeljenim na ANOVA analizi varijance, $p<0,05$. Promjene temperature, apsorbancije i gustoće prikazane su 3D kategorijskim dijagramima kategoriziranim prema masi sojinog zrna za pripravu sojinog mlijeka prema referentnim vrijednostima: $\mathrm{T}=20^{\circ} \mathrm{C} ; \mathrm{A}(500 \mathrm{~nm})=0,953 ; \rho=$ $1,0025 \mathrm{gcm}^{-3}$. Raspodjela veličine masnih globula grafički je prikazana odnosom relativne učestalosti o promjeru masnih globula (Log - N raspodjela). Apsorbancija nakon 24 sata prikazana je pomoću $\beta$ - koeficijenata zbog male razlike u mjerenim vrijednostima koji ukazuju na povećanu stabilnost uzoraka. 
Tablica 1. Utjecaj procesnih parametara na promatrana fizikalna svojstva obzirom na standardizirani koeficijent utjecaja [ß]. Table 1. Influence of process parameters on physical properties considering on standardized coefficient $[\beta]$.

\begin{tabular}{|c|c|c|c|c|c|c|c|}
\hline $\begin{array}{c}\text { Ultrazvuk/Ultrasound } \\
\text { Visoki hidrostatski } \\
\text { tlak/High Hydrostatic } \\
\text { Pressure }\end{array}$ & $\mathbf{A}[\mathbf{6 \%}]$ & $\begin{array}{c}\mathbf{t} \\
{[\mathbf{m i n}]}\end{array}$ & $\begin{array}{c}\mathbf{d} \\
{[\mathbf{m m}]}\end{array}$ & $\begin{array}{c}\mathbf{m} \\
\mathbf{[ g ]}\end{array}$ & $\begin{array}{c}\mathrm{P} \\
{[\mathrm{MPa}]}\end{array}$ & $\begin{array}{c}\mathrm{t} \\
{[\mathrm{min}]}\end{array}$ & $\begin{array}{c}\mathrm{m} \\
{[\mathrm{g}]}\end{array}$ \\
\hline $\mathbf{T}\left[{ }^{\circ} \mathbf{C}\right]$ & 16,929 & 4,721 & 12,406 & $/$ & - & - & - \\
\hline $\mathbf{A}[\mathbf{5 0 0 n m}]$ & $/$ & $/$ & $-11,504$ & 122,934 & $/$ & $-2,468$ & 45,225 \\
\hline $\mathbf{A}_{24}[\mathbf{5 0 0 n m}]$ & 7,870 & $/$ & $-2,588$ & 191,407 & $/$ & $/$ & 46,893 \\
\hline $\mathbf{\rho}\left[\mathbf{g c m}^{-3}\right]$ & 10,394 & 2,369 & $-9,435$ & 172,148 & $-2,219$ & $-3,358$ & 70,160 \\
\hline
\end{tabular}

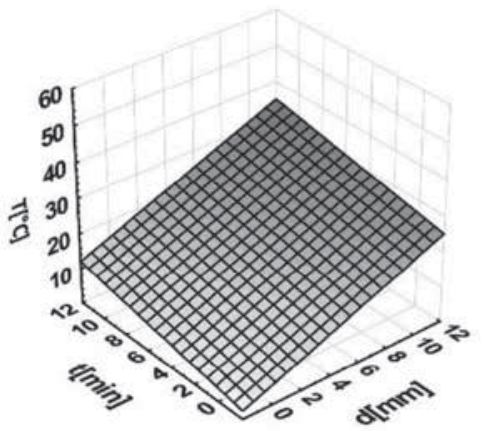

$\mathrm{m}=50 \mathrm{~g}$

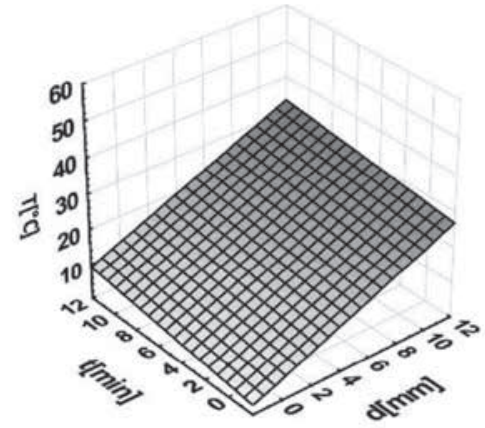

$\mathrm{m}=90 \mathrm{~g}$

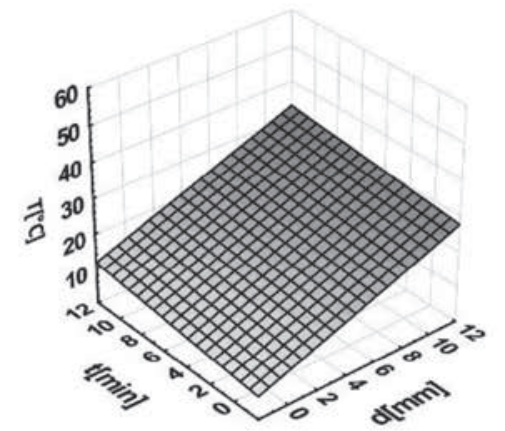

$m=130 \mathrm{~g}$

\section{$>30 \square<24 \square<14 \square<4$}

Slika 1. Utjecaj parametara ultrazvuka (amplituda, vrijeme obrade i promjer sonde) na temperaturu kategorizirano prema masi sojinog zrna

Figure 1. Influence of ultrasonic parameters (amplitude, time of treatment and probe diameter) on temperature categorized by soybean weight

Temperatura kao jedno od najvažnijih fizikalnih svojstava direktno utječe na promjenu fizikalnih svojstava promatrane disperzne faze i disperznog sredstva (Bosiljkov, 2011). Tijekom obrade ultrazvukom promjena temperature u okolnom mediju kao posljedica djelovanja širenja ultrazvučnog vala konstantne frekvencije, amplitude i ciklusa kroz određeni vremenski interval stvara mehaničke vibracije, tj. mehaničko valno gibanje koje uključuje odlike izlazne veličine koja statistički značajno mijenja fizikalna svojstva analiziranih uzoraka u promatranom sustavu (Ashokkumar i sur., 2008; Ashokkumar, 2011). Utjecaji amplitude, vremena obrade i promjera sonde imaju statistički značajan utjecaj na povišenje temperature sojinog mlijeka. Parametar koji obrađene uzorke sojinog mlijeka, obzirom na različiti udio suhe tvari čini selektivnim je amplituda i primjena sonde različitog promjera. Sonda igra veliku ulogu kod ultrazvučnih procesora manje akustičke snage. Odabir sonde vrši se na osnovu procjene željenog utjecaja u mediju koji se obrađuje. Procesori veće akustičke snage dovode do željenog utjecaja i sondom manjeg promjera. Utjecaj procesnih parametara na povišenje temperature kao posljedice valnog gibanja kroz medij uvjetovano je kemijskim sastavom i udjelom suhe tvari uzoraka sojinog mlijeka. Najvažnija komponenta je udio masti i proteina u mlijeku (Bosiljkov, 2011).
Rasprostiranje ultrazvučnog vala u mlijeku sa manjim udjelom masne faze je intenzivnije čime se potiče stvaranje većeg broja manjih kavitacijskih mjehurića čijom se implozijom oslobađa toplina koja uzrokuje trenutno povišenje temperature u neposrednoj okolini. Michalski i Januel (2006) navode optimalne temperaturne intervale unutar kojih se učinak homogenizacije povećava u rasponu od $42-72{ }^{\circ} \mathrm{C}$, a stabilizacija disperzne faze (globula) postiže se u rasponu od $72-77{ }^{\circ} \mathrm{C}$. Promatrajući Sliku 1 vidljivo je da različiti udio suhe tvari nema značajan utjecaj na povišenje temperature, $\mathrm{tj}$. temperaturni maksimumi kreću se u intervalu od $32-35^{\circ} \mathrm{C}$ korištenjem sonde promjera $7 \mathrm{~mm}$, dok se temperaturni maksimumi sondom promjera 10 $\mathrm{mm}$ kreću u intervalu $42-45^{\circ} \mathrm{C}$. 


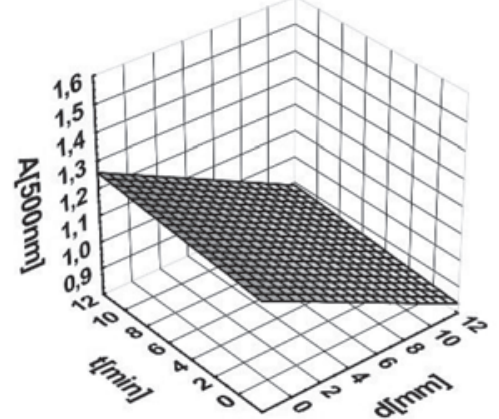

$\mathrm{m}=50 \mathrm{~g}$

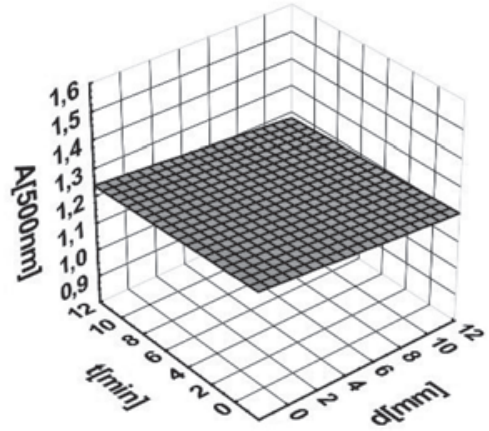

$\mathrm{m}=90 \mathrm{~g}$

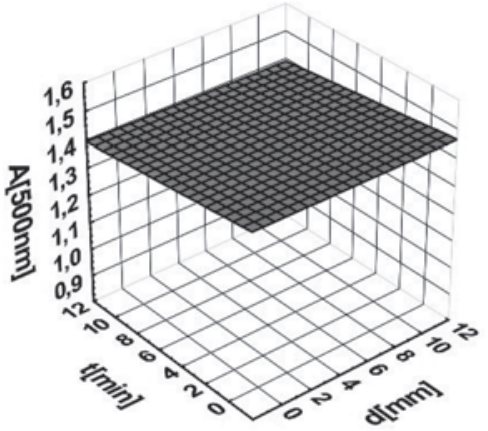

$\mathrm{m}=130 \mathrm{~g}$

\section{$\square>1,4 \square<1,25 \quad \square<1,15 \square<1,05 \quad \square<0,95 \quad \square<0,85$}

Slika 2. Utjecaj parametara ultrazvuka (amplituda, vrijeme obrade i promjer sonde) na apsorbanciju [500nm] kategorizirano prema masi sojinog zrna

Figure 2. Influence of ultrasonic parameters (amplitude, time of treatment and probe diameter) on absorbance [500nm] categorized by soybean weight

Amplituda i vrijeme obrade nemaju statistički značajan utjecaj na apsorbanciju sojinog mlijeka. Sukladno očekivanom vrijednosti apsorbancije i apsorbancije nakon 24 sata karakteriziraju visoke vrijednosti $\beta$ - koeficijenata $(122-191)$ kako se povećava udio suhe tvari. Mjerenjem apsorbancije nakon 24 sata želi se ukazati na male razlike u izmjerenim vrijednostima neposredno nakon obrade što ukazuje na visoku stabilnost ovako pripremljenih uzorka kroz dulji vremenski period pri čemu u potpunosti ostaje očuvana fluidnost faza. Najveće odstupanje vidljivo je kod povećanje promjera sonde gdje dolazi do statistički značajnog, ali negativnog utjecaja $\beta$ - koeficijenta (50 g) što pokazuje uzorak sojinog mlijeka gdje se najveća stabilnost postiže sondom promjera $7 \mathrm{~mm}$ neovisno o vremenom obrade (Slika 2). Ovakav trend ukazuje na kvalitetu, visoku učinkovitost i prije svega racionalnost primjene ultrazvuka u postupku homogenizacije.

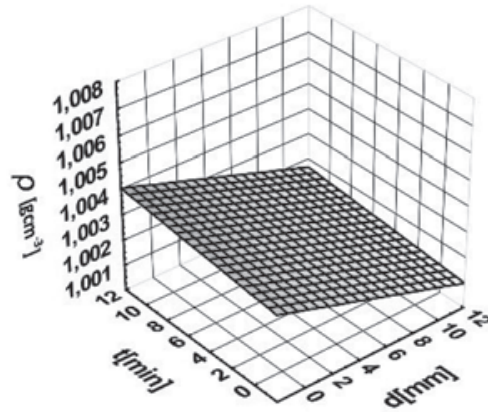

$m=50 g$

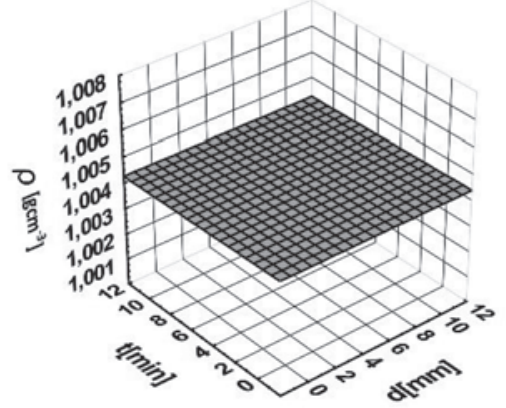

$m=90 g$

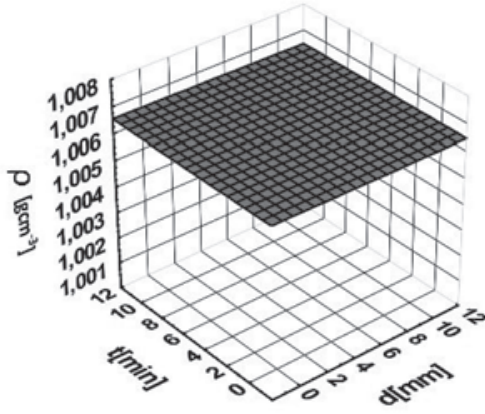

$m=130 \mathrm{~g}$
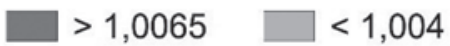

$<1,003$

$<1,002$

$<1,001$

Slika 3. Utjecaj parametara ultrazvuka (amplituda, vrijeme obrade i promjer sonde) na gustoću kategorizirano prema masi sojinog zrna

Figure 3. Influence of ultrasonic parameters (amplitude, time of treatment and probe diameter) on density categorized by soybean weight

Gustoća sojinog mlijeka ovisi o početnoj masi zrna kao i stupnju ekstrakcije sojinog zrna tijekom proizvodnje sojinog mlijeka. Na povećanje vrijednosti gustoće statistički značajan utjecaj ima povećanje amplitude i vrijeme obrade, kao i povećanje udjela suhe tvari u uzorcima mlijeka (Slika 3). Povećanjem masenog udjela zrna u sojinom mlijeku povećava se i sama gustoća mlijeka što je i vidljivo iz visoke vrijednosti standardiziranog koeficijenta utjecaja $(\beta=172,148)$ u odnosu na utjecaje ostalih statistički značajnih procesnih parametara.
Osim navedenog optimizacija procesnih parametara od velike je važnosti jer ako uzorak mlijeka sadržava veliki broj masnih globula velikog promjera $(>4 \mu \mathrm{m})$ i pri tome se obrađuje duže vrijeme maksimalnom amplitudom može doći do pojave ponovnog međusobnog sudaranja i djelomičnog združivanja globula. Ova pojava prouzrokovana je visokom temperaturom uzorka. Ponovno nakupljanje globula uzrokuje povećanje vrijednosti gustoće u odnosu na globule prije obrade (Chandan, 2007). 


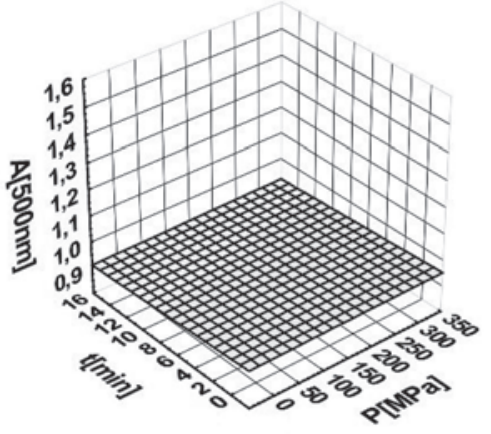

$\mathrm{m}=50 \mathrm{~g}$

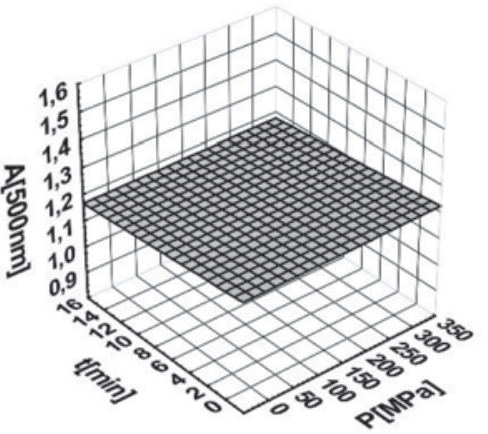

$m=90 g$

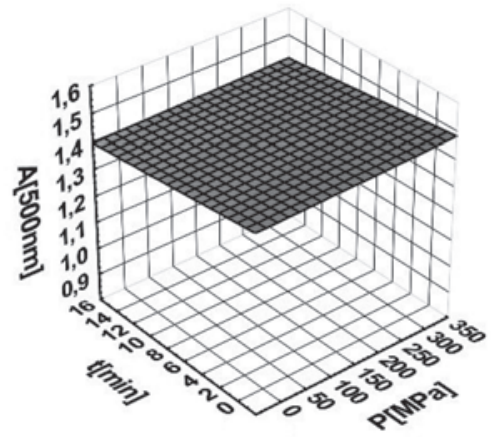

$m=130 \mathrm{~g}$

\section{$>1,4 \quad \square<1,2 \quad \square<0,925$}

Slika 4. Utjecaj visokog hidrostatskog tlaka i vremena obrade na apsorbanciju [500nm] kategorizirano prema masi sojinog zrna Figure 4. Influence of high hydrostatic pressure and time of treatment on absorbance [500nm] categorized by soybean weight

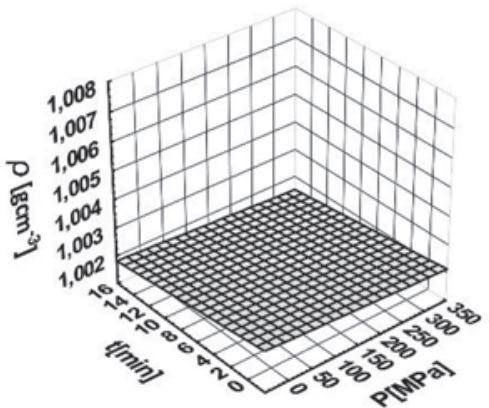

$m=50 \mathrm{~g}$

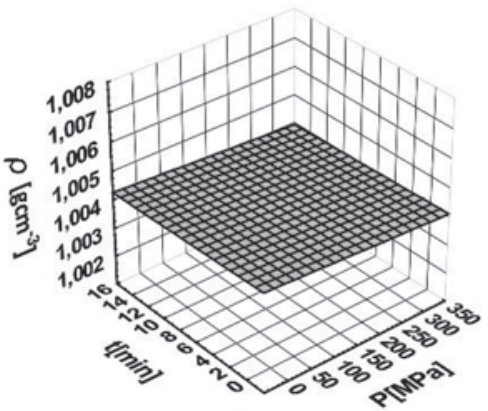

$m=90 \mathrm{~g}$

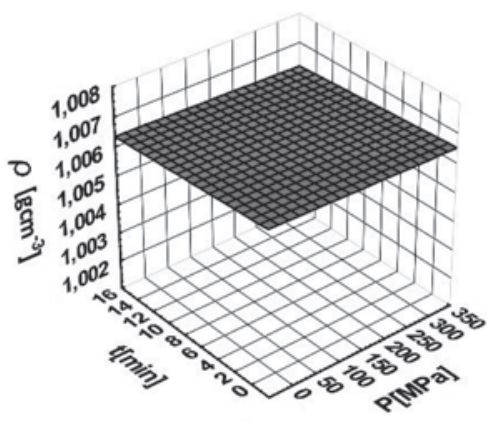

$m=130 \mathrm{~g}$

$$
>1,0063 \square<1,0063 \square<1,0025 \quad \mid<1,0015
$$

Slika 5. Utjecaj visokog hidrostatskog tlaka i vremena obrade na gustoću kategorizirano prema masi sojinog zrna Figure 5. Influence of high hydrostatic pressure and time of treatment on density categorized by soybean weight

Budući da se povišenjem visokog hidrostatskog tlaka za svakih $100 \mathrm{MPa}$ u prosjeku povisuje temperatura uzoraka za $3{ }^{\circ} \mathrm{C}$, nakon obrade temperaturni maksimumi nisu prelazili 35 ${ }^{\circ} \mathrm{C}$ što je u usporedbi sa ultrazvučnim maksimumima prednost prema cilju očuvanja senzorskih svojstava tako obrađenih uzoraka. Visoki hidrostatski tlak odlikuju nešto slabije izraženi utjecaji procesnih parametara na promatrana fizikalna svojstva.
Kao i kod ultrazvuka povećanje udjela suhe tvari dovodi do povećanja vrijednosti apsorbancije (Slika 4) i gustoće. Neovisno o većoj gustoći uzoraka sa većim udjelom suhe tvari utjecaj povećanja vrijednosti visokog tlaka $(\beta=-2,219)$ i duljim vremenom obrade $(\beta=-3,358)$ u konačnici je rezultirao smanjenjem gustoće sojinog mlijeka (Slika 5).

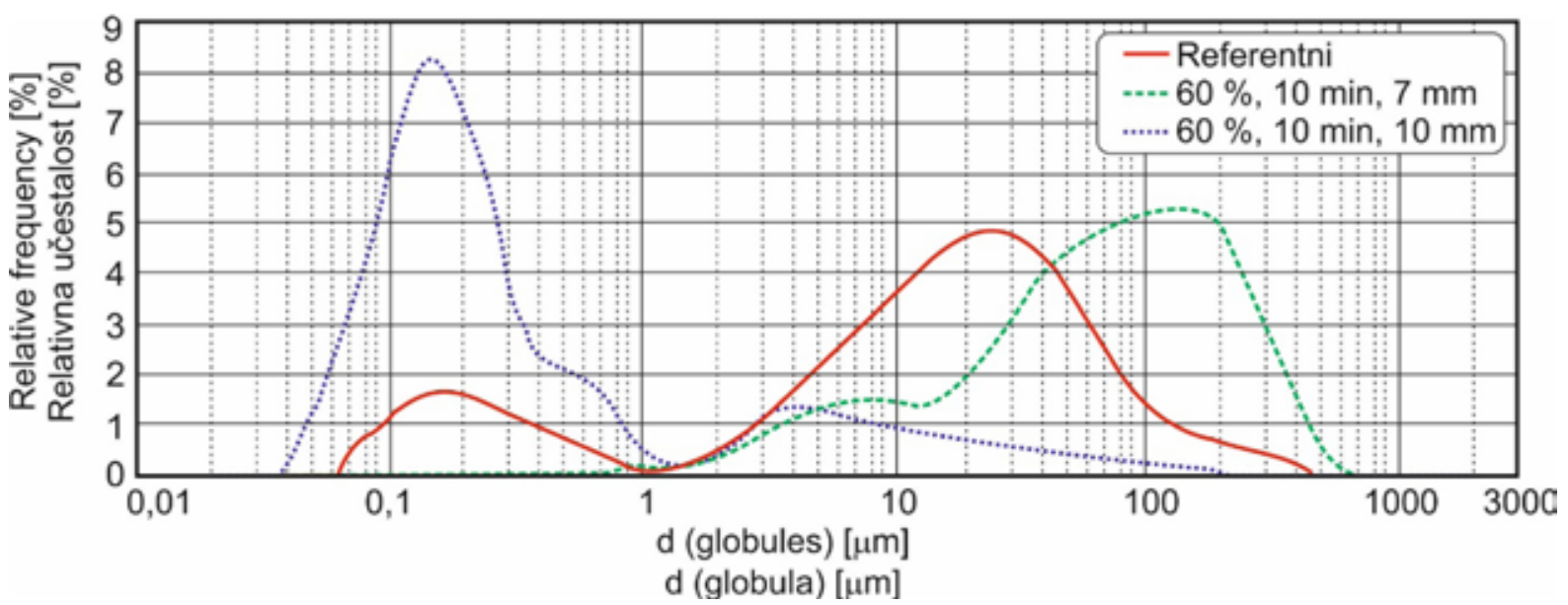

Slika 6. Utjecaj ultrazvuka na Log - N raspodjelu sojinog mlijeka (50 g)

Figure 6. Influence of ultrasound on Log $-N$ distribution of soy milk (50 g) 


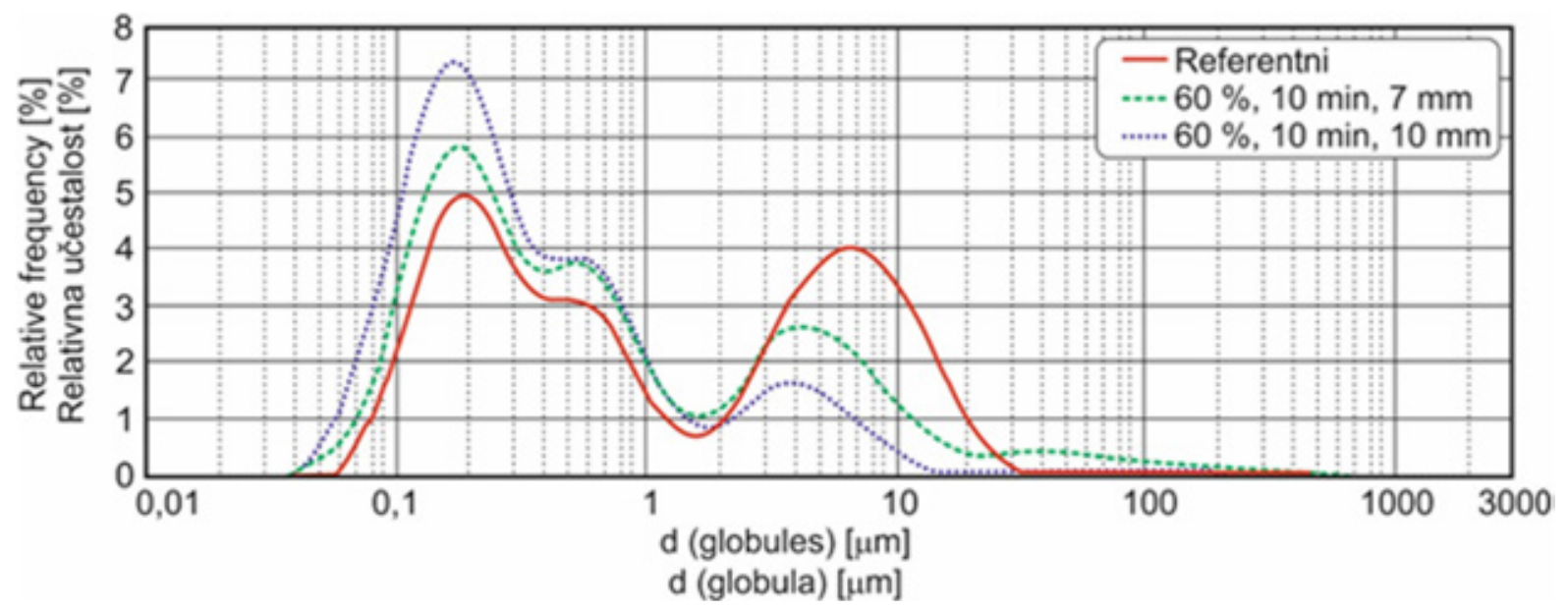

Slika 7. Utjecaj ultrazvuka na Log - N raspodjelu sojinog mlijeka (90 g)

Figure 7. Influence of ultrasound on Log - N distribution of soy milk (90 g)

Analiza raspodjele veličine čestica sojinog mlijeka prvenstveno se provodi zbog individualnog karaktera ovako obrađenih uzoraka koji posljedično ukazuju na potencijalnu stabilnost. Osim raspodjele čestica važno je detektirati i eventualno nastale agregate koji mogu biti detektirani kao čestice velikog promjera (Poliseli - Scopel i sur., 2012). Na Slikama 6 i 7 prikazana je raspodjela veličine masnih globula sojinog mlijeka pripravljenih ekstrakcijom 50 i 90 g sojinog zrna i obrađenih ultrazvukom. Prikazane su frekvencijske krivulje pri amplitudi $60 \%$, vremenu obrade 10 minuta sa sondama 7 i 10 $\mathrm{mm}$. Raspodjela veličine masnih globula kreće se u intervalu od $0,03-100 \mu \mathrm{m}$. Relativna učestalost čestica u intervalu raspodjele od $10-100 \mu \mathrm{m}$ odnosi se isključivo na zaostale ljuske sojinog zrna nakon ekstrakcije i filtracije. Učestalost nečistoća i primjesa moguće je svesti na najmanju moguću mjeru korištenjem filter papira sa sitnijim otvorima pora. Kod oba uzorka vidljivo je povećanje relativne učestalosti primjenom sonde 10 $\mathrm{mm}$ i povećanje intervala raspodjele $\mathrm{u}$ području od $0,03-1$ $\mu \mathrm{m}$. Prema Bosiljkov, 2011; Karlović i sur., 2014 vrijednost varijance kreću se u intervalu od 0,2 - 0,6 i raspodjele veličine masnih globula od $0,5-4 \mu \mathrm{m}$ gdje se tako obrađena prirodna emulzija smatra izrazito stabilnom i homogenom. Kod mlijeka pripravljenog ekstrakcijom 90 g sojinog zrna primjećuje se pomak obje frekvencijske krivulje unutar bimodalnog područja i povećanja relativne učestalosti u intervalu raspodjele od 0,5 $-1 \mu \mathrm{m}$.

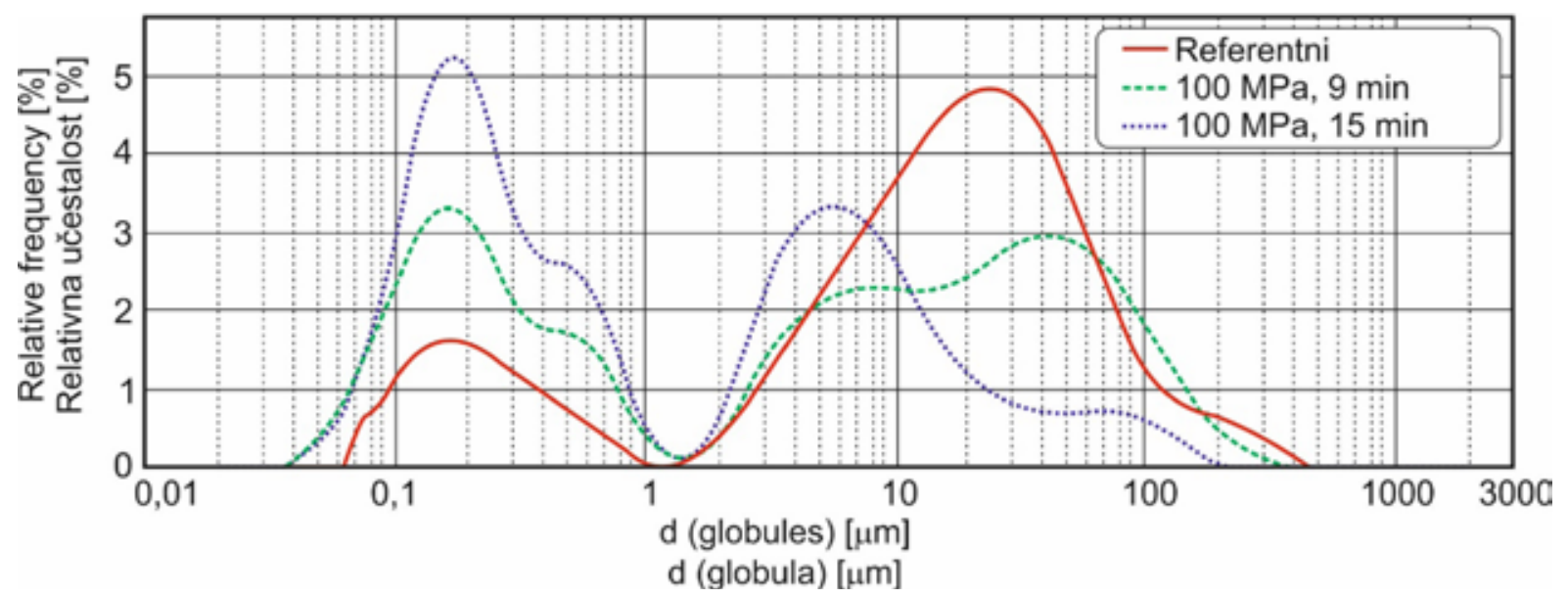

Slika 8. Utjecaj visokog hidrostatskog tlaka na Log - N raspodjelu sojinog mlijeka (50 g)

Figure 8. Influence of high hydrostatic pressure on $\log -N$ distribution of soy milk $(50 \mathrm{~g})$ 


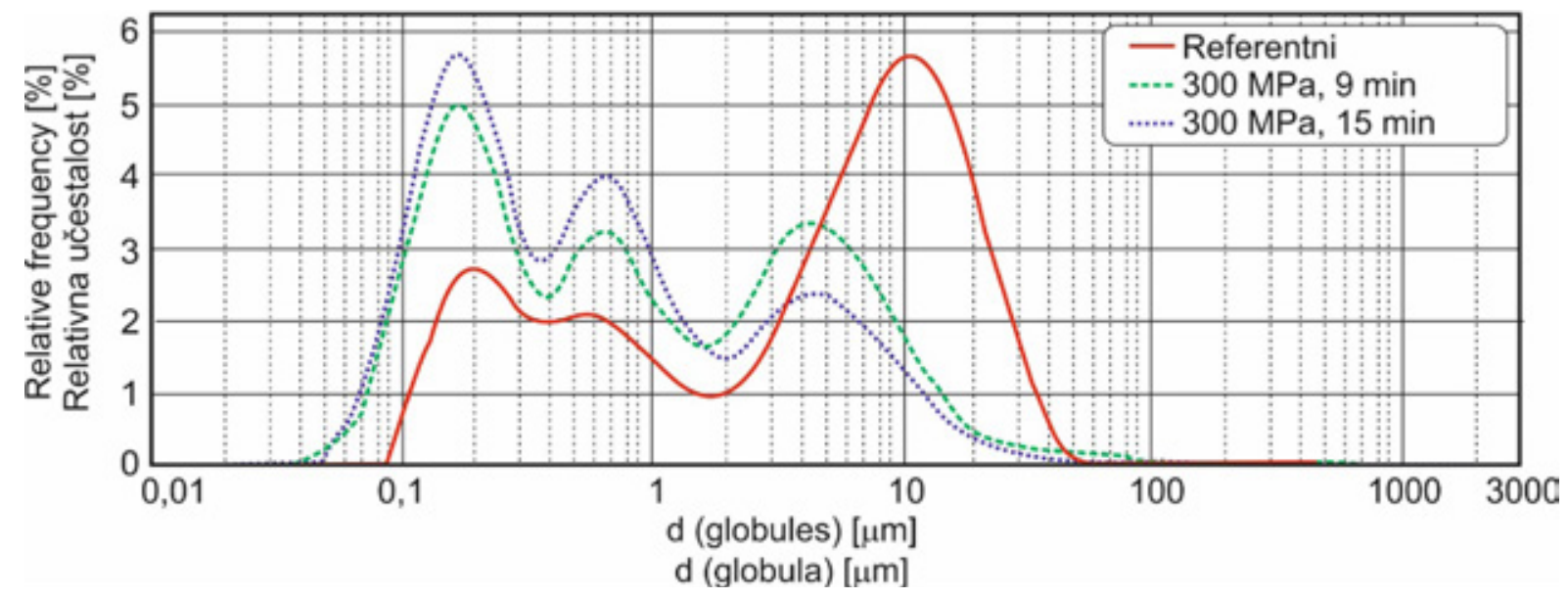

Slika 9. Utjecaj visokog hidrostatskog tlaka na Log - N raspodjelu sojinog mlijeka (130 g)

Figure 9. Influence of high hydrostatic pressure on Log - N distribution of soy milk (130 g)

Promatrajući utjecaj visokog hidrostatskog tlaka od 100 i $300 \mathrm{MPa}$ i vremenu obrade od 9 i 15 minuta najveći frekvencijski pomak je kod mlijeka sa $50 \mathrm{~g}$ sojinog zrna. Kod tlaka 100 MPa (Slika 8) vidljiv je utjecaj duljeg vremena obrade i porast intervala masnih globula od $0,03-1 \mu \mathrm{m}$. Pri tlaku od $300 \mathrm{MPa}$ vidljiva je postojanost i preklapanje krivulja unutar bimodalnog područja. Kod mlijeka pripravljenog s 90 g sojinog zrna nisu uočene značajne razlike u promjeni učestalosti u odnosu na referentni tj. nehomogenizirani uzorak. Uzorci dobiveni sa $130 \mathrm{~g}$ (Slika 9) sojinog zrna pokazuju svojstva stabilnosti i homogenosti unutar intervala raspodjele $0,03-10 \mu \mathrm{m}$. Multimodalnost ovih krivulja ukazuju na nestabilnost i djelomično homogen uzorak kojeg karakteriziraju tri nestabilna pika. Uspoređujući uzorak $130 \mathrm{~g}$ u odnosu na uzorke 50 i 90 g pomak frekvencijske krivulje izraženiji je prema manjim vrijednostima promjera masnih globula u odnosu na referentnu vrijednost.

\section{Zaključci}

Sojino mlijeko obrađeno ultrazvukom pokazuje nešto veću stabilnost u odnosu na proizvod dobiven visokim hidrostatskim tlakom. Fizikalna svojstva obrađenog sojinog mlijeka sa intervalom raspodjele masnih globula od 0,03 - $5 \mu \mathrm{m}$ ukazuju na stabilan sustav koji u sinergiji sa odabranim voćem ili povrćem pokazuje svojstva dobre održivosti. Promatrajući procese sa energetskog aspekta visoki hidrostatski tlak je daleko isplativiji jer primjenom nižih vrijednosti hidrostatskog tlaka i kraćim vremenom obrade dobivamo stabilan proizvod kroz dulji vremenski period. Sukladno dobivenim rezultatima vidljivo je da su svi pripravci sojinog mlijeka sa različitim udjelom suhe tvari obrađeni ultrazvukom ili visokim hidrostatskim tlakom pogodni kao baza za pripravu napitaka od voća, povrća i smoothija.

\section{Zahvala}

Rad je izrađen u sklopu projekta HRZZ (Hrvatska zaklada za znanost) pod nazivom „Primjena visokog hidrostatskog tlaka u proizvodnji funkcionalnih sokova na bazi voća i povrća“ (IP 2016 - 06 - 4006) čiji je voditelj Prof.dr.sc. Damir Ježek.

\section{Literatura}

Ashokkumar, M. (2011) The caracterization of acoustic cavitation bubbles - An overwiev. Ultrasonic Sonochemistry, $18864-872$.

Ashokkumar, M., Sunartio, D., Kentish, S., Mawson, R., Lloyd, S., Vikhu, K., Versteeg, C.K. (2008) Modification of food ingredients by ultrasound to improve functionality: A preliminary study on a model system. Innovative Food Science and Emerging Technologies, 9155 - 160.

Bosiljkov, T., Tripalo, B., Ježek, D., Brnčić, M., Karlović, S. (2010) Princip rada i primjena visokih tlakova u prehrambenoj industriji. Kemija u industriji: časopis kemičara i tehnologa Hrvatske, 59 (11) 539 - 544.

Bosiljkov, T. (2011) Doctoral Thesis, Influence of high intensity ultrasound on degree of homogenization and physical properties of soybean, cow, sheep and goat milk, University of Zagreb, Faculty of Food Technology and Biotechnology, Zagreb.

Bosiljkov, T., Dujmić, F. Cvjetko Bubalo, M., Hribar, J., Vidrih, R., Brnčić, M., Zlatić, E., Radojčić Redovniković, I., Jokić, S. (2017) Natural deep eutectic solvents and ultrasoundassisted extraction: green approaches for extraction of wine lees anthocyanins. Food and bioproducts processing, 102195 $-203$.

Chandan, R.C. (2007) Milk Composition, Physical and Processing Characteristics. U: Handbook of Food Products Manufacturing, vol.2 (Hui, Y. H., ured. ), John Wiley \& Sons, Inc., Hoboken, New Jersey, 348-377.

Fernandez M.V., Denoya G.I., Agüero M.V., Jagus R.J., Vaudagna S.R. (2018) Optimization of high pressure processing parameters to preserve quality attributes of a mixed fruit and vegetable smoothie. authors. Please check if appropriate. doi:10.1016/j.ifset.2018.02.011

Indrawati, Van Loey, A., Hendrickx, M. (2002) High pressure processing. U: Henry, C. J. K., Chapman, C. (ed): The nutrition handbook for food processors, str. 433 - 461. Woodhead Publishing Ltd, Cambridge.

Karlović, S., Bosiljkov, T., Brnčić, M., Semenski, D., Dujmić, F., Tripalo, B., Ježek, D. (2014) Reducing Fat Globules Particle-Size in Goat Milk: Ultrasound and High Hydrostatic 
Pressures Approach. Chemical and Biochemical Engineering Quarterly, 28499 - 507.

Komes, D., Bušić, A., Belščak-Cvitanović, A., Brnčić, M., Bosiljkov, T., Vojvodić, A., Dujmić, F. (2017) Novel Approach to the Development of Functional Goat's Milk-Based Beverages Using Medicinal Plant Extracts in Combination with High Intensity Ultrasound Treatment. Food technology and biotechnology, 55 (4) 484 - 495.

Martínez-Monteagudo, S. I., Balasubramaniam, V. M. (2015) Fundamentals and Applications of High- Pressure Processing Technology. U: Balasubramaniam, V. M., Barbosa-Cánovas, G. V., Lelieveld, H. L. M., (ed): High Pressure Processing of Food: Principles, Technology and Applications, str. 3-17. Springer Science+Business Media LLC, New York.

Michalski, M.C., Januel, C. (2006) Does homogenization affect the human health properties of cow's milk? Trends in Food Science and Technology, 17423 - 437.

Picouet, P.A., Hurtado, A., Jofre, A., Banon, S., Ros, J-M., Dolors Guardia, M. (2016) Effects of thermal and high - pressure treatments on the microbiological nutritional and sensory quality of a multi - fruit smoothie. Food Bioprocess Technology, DOI 10.1007/s11947-016-1705-2

Tewari, G. (2007) High-Pressure Processing of Foods. U: Advances in Thermal and Non-Thermal Food Preservation (Tewari, G., Juneja, V. K., ured.), Blackwell Publ., New York, str. $203-241$.

Toro - Funes, N., Bosch - Fuste, J., Veciana - Nogues, M.T., Vidal - Carou, M.C. (2014) Effect of ultra high pressure homogenization treatment on the bioactive compounds of soya milk. Food Chemistry, 152597 - 602.

Poliseli - Scopel Fabio, H., Hernandez - Herrero, M., Guamis, B., Ferragut, V. (2012) Comparison of ultra high pressure homogenization and conventional thermal treatments on the microbiological, physical and chemical quality of soymilk. Food Science and Technology, 4642 - 48. 